\section{Radiation Therapy (RT) target determination for irradiation of bone metastases with soft tissue component: Impact of multimodality imaging}

\section{Omer Sager*, Ferrat Dincoglan, Selcuk Demiral and Murat Beyzadeoglu}

Department of Radiation Oncology, University of Health Sciences, Gulhane Medical Faculty, Ankara, Turkey
Received: 28 February, 2021

Accepted: 18 March, 2021

Published: 19 March, 2021

*Corresponding authors: Omer Sager, Department of Radiation Oncology, University of Health Sciences, Gulhane Medical Faculty, Ankara, Turkey, E-mail: +90 312304 4683; Fax: +90 312304 4680; E-mail: omersager@gmail.com ORCID: https://orcid.org/0000-0001-7866-2598

Keywords: Radiation Therapy (RT); Bone metastasis; Soft tissue component; Magnetic Resonance Imaging (MRI)

https://www.peertechzpublications.com

\section{Check for updates}

\title{
Abstract
}

Objective: Management options for bone metastases include surgical interventions, Radiation Therapy (RT), chemotherapy and other systemic and targeted agents. RT as external beam irradiation and by use of stereotactic radiotherapeutic approaches has been utilized for safe and efficacious management of bone metaseses. In the context of bone metastases with extraosseous soft tissue mass, the issue of irradiation target definition is a critical component of radiotherapeutic management for successful treatment. Herein, we evaluated target definition for irradiation of bone metastases with soft tissue component by incorporation of multimodality imaging.

Materials and methods: RT target definition for irradiation of bone metastases with soft tissue component was assessed in this study.

Results: Patients receiving palliative irradiation for bone metastases with soft tissue component were assessed for target volume determination. Treatment planning process was performed using the Elekta Precise treatment planning system (Elekta, UK) at our department. Definition of ground truth target volume was performed by the board certified radiation oncologists following meticulous evaluation, colleague peer review, collaboration, and ultimate consensus. Synergy (Elekta, UK) LINAC was used for irradiation. Comparative assessment in our study revealed that ground truth target volume was identical with target volume definition by CT-MR fusion based imaging.

Conclusion: Incorporation of multimodality imaging in target definition of bone metastases with soft tissue component may be utilized for improving the accuracy for precise RT despite the need for further supporting evidence.

\section{Introduction}

Bone metastases are among the frequent complications of systemic cancer, and a significant proportion of patients suffer from bone metastases during the course of their malignant disease [1]. Metastases may occur in the form of a single metastatic bone lesion, oligometastatic disease, multiple bone metastases, or visceral metastases with bone metastases. Most frequently affected site includes the vertebrae followed by femur, pelvic bones, ribs, sternum, humerus, and skull. While aymptomatic presentation may be present, affected patients may suffer from a variety of symptoms depending on metastatic disease location, extent and association with critical neurovascular structures. Skeletal related events due to bone metastases may include pain, compression of nerve roots and the spinal cord, hypercalcemia, myelophthisis, and pathological fractures which could lead to severe consequences and quality of life impairment.

Pain is a very frequent symptom of bone metastases $[1,2]$. Osteoclasts are thought to play significant role in pathophysiology, and injury of bone and nerve fibers may be responsible for occurrence of pain with both a nociceptive and neuropathic component [3-6].

Management options for bone metastases include surgical interventions, radiation therapy (RT), chemotherapy and 
other systemic and targeted agents [4-12]. RT as external beam irradiation and by use of stereotactic radiotherapeutic approaches has been utilized for safe and efficacious management of bone metaseses [4-12]. In the context of bone metastases with extraosseous soft tissue mass, the issue of irradiation target definition is a critical component of radiotherapeutic management for successful treatment. Herein, we evaluated target definition for irradiation of bone metastases with soft tissue component by incorporation of multimodality imaging.

\section{Materials and methods}

RT target definition for irradiation of bone metastases with soft tissue component was assessed in this study. Comparative analysis of Computed Tomographhy (CT)-only imaging and CT-magnetic resonance imaging (MRI) based target definition was performed to evaluate the impact of multimodality imaging. Ground truth target volume serving as the reference for actual treatment and comparison purposes was meticulously determined by board certified radiation oncologists following thorough evaluation, colleague peer review, collaboration, and ultimate consensus. All patients included in the study had histopathologically proven cancer diagnosis with radiological verification of bone metastases. Individualized patient assessment was performed to assess lesion size and localization, presenting symptoms, patient preferences, and contemplated outcomes of palliative treatment.

CT-simulator (GE Lightspeed RT, GE Healthcare, Chalfont St. Giles, UK) was utilized for RT simulation for all patients. Planning CT images were acquired and then transferred to the delineation workstation (SimMD, GE, UK) for outlining of target volume and organs at risk (OARs). Either CT-simulation images only or fused CT and MR images were utilized for target volume definition for radiotherapeutic management of bone metastases with soft tissue component. Contoured structure sets were transferred to the Elekta Precise treatment planning system (Elekta, UK) for radiation treatment planning. IGRT was routinely used by incorporating kilovoltage Cone Beam Computed Tomography (kV-CBCT) and X-ray Volumetric Imaging (XVI, Elekta, UK) for setup verification of each patient. Dose fractionation scheme included 30 Gy delivered in 10 fractions over 2 weeks, 20 Gy delivered in 5 fractions over 1 week, or 8 Gy delivered in a single fraction.

Target definition with CT only and with incorporation of CT-MR fusion based imaging was assessed comparatively. Also, patients were also assessed for age, gender, primary cancer diagnosis, location of metastases, and performance status.

\section{Results}

Patients receiving palliative irradiation for bone metastases with soft tissue component were assessed for target volume determination based on CT-only imaging and CT-MRI. Patient, tumor, and treatment charactheristics are summarized in Table 1.
Table 1: Patient, tumor and treatment characteristics.

\begin{tabular}{|c|c|c|}
\hline Characteristic & Number & $\%$ \\
\hline Number of patients & 20 & \\
\hline Median age (range) & $63(51-83)$ years & \\
\hline Median KPS (range) & $70(50-100)$ & 55 \\
\hline Gender & & 45 \\
Male & 11 & \\
Female & 9 & 35 \\
\hline Primary tumor histology & & 30 \\
Prostate Ca & 7 & 25 \\
Breast Ca & 6 & 10 \\
Lung Ca & 5 & 40 \\
Other & 2 & 25 \\
\hline Involved metastatic region & & 20 \\
hips and pelvis & 8 & 10 \\
\hline lumbar spine & 5 & 10 \\
thoracic spine & 4 & 60 \\
lower limbs & 2 & 30 \\
other & 1 & 10 \\
\hline Dose fractionation scheme & 12 & 6 \\
\hline Gy in 10 fractions over 2 weeks & 2 & \\
\hline Gy in fractions over 1 week & & \\
\hline Gy in 1 fraction & & \\
\hline
\end{tabular}

A total of 20 patients were included in the study. Median age was 63 years (range: $51-83$ years). Eleven patients (55\%) were male and 9 patients $(45 \%)$ were female. Involved metastatic region included the hips and pelvis in 8 patients $(40 \%)$, lumbar spine in 5 patients (25), thoracic spine in 4 patients $(20 \%)$, lower limbs in 2 patients $(10 \%)$, and other location in 1 patient (5\%). Median Karnofsky Performance Status was 70 (range: 50-100). Primary diagnosis was prostate cancer, breast cancer, lung cancer, and other for 7 patients (35\%), 6 patients $(30 \%)$, 5 patients $(25 \%)$, and 2 patients $(10 \%)$, respectively. Dose fractionation scheme included 30 Gy delivered in 10 fractions over 2 weeks in 12 patients $(60 \%), 20$ Gy delivered in 5 fractions over 1 week in 6 patients $(30 \%)$, or 8 Gy delivered in a single fraction in 2 patients $(10 \%)$.

Treatment planning process was performed using the Elekta Precise treatment planning system (Elekta, UK) at our department. Sparing of OARs whilst encompassing the target volumes were primary objectives of optimized treatent planning. Definition of ground truth target volume was performed by the board certified radiation oncologists following meticulous evaluation, colleague peer review, collaboration, and ultimate consensus. Synergy (Elekta, UK) LINAC was used for irradiation. Comparative assessment in our study revealed that ground truth target volume was identical with target volume definition by CT-MR fusion based imaging and a $100 \%$ overlap was detected between CT-MR fusion based target volume definition and ground truth target volume determination by the board certified radiation oncologists following comprehensive assessment, collaboration, colleague peer review, and ultimate consensus.

\section{Discussion}

Bone metastases constitute a very frequent complication of advanced systemic cancer. Pain, hypercalcemia, spinal cord compression and related symptoms are among the potential 
consequences which may lead to profound deterioration in affected patients. Among the several promising therapeutic strategies, RT deserves utmost attention as a viable mode of palliative management. There has been extensive study for finding out the optimal radiotherapeutic approach and dose fractionation schemes, however, there seems to be no standard solution to fit all circumstances which indicates the importance of considering individual patient and disease characteristics in the decision making process.

Several factors may be considered in management such as performance status, treatment compliance, life expectancy, primary cancer diagnosis, localization of metastatic lesions, presence of soft tissue involvement, fractures or neurological deficits, and logistical issues. Source availability, staffing, and facility workload may also be taken into account. Clearly, the goal of management shoud include.

In the era of extremely focused irradiation techniques such as stereotactic body RT (SBRT), it has been more critical to define target volume accurately. From this standpoint, exploiting the advantages of multimodality imaging for precise target definition has been an indispensable component of successful patient management in the millenium era.

There have been several studies exploring the role of multimodality imaging in target definition for radiotherapeutic management of several entities [13-40]. Substantial progress has been achieved in recent years with adoption of adaptive RT strategies and modernized treatment delivery techniques and equipment with incorporation of Intensity Modulated Radiation Therapy (IMRT), Adaptive Radiation Therapy (ART), Breathing Adapted Radiation Therapy (BART), IGRT, automatic segmentation techniques, molecular imaging methods, and stereotactic irradiation approaches [41-75].

Regarding management of bone metastases, use of RT has been addressed for effective palliation [4-12]. With efficacious local and systemic treatment approaches, there have been improvements in survival of patients suffering from metastatic cancer. Longer life expectancy of patients has rendered quality of life a critical aspect of successful management. Contemporary radiotherapeutic strategies increase the importance of precise RT target definition for an improved therapeutic ratio. Within this context, incorporation of multimodality imaging in target definition of bone metastases with soft tissue component may be utilized for improving the accuracy for precise RT. Admittedly, definition of the ground truth target volume for utilization in actual treatment and comparison purposes may be considred as a critical issue prone to variations due to possible interobserver variations. In this study, board certified radiation oncologists have performed definition of ground truth target volume following detailed evaluation, colleague peer review, collaboration, and ultimate consensus to achieve optimal results.

\section{Conclusion}

Bone metastases comprise a common complication of systemic cancer. Avoidance of excessive radiation induced toxicity is a critical concern for radiotherapeutic management of bone metastases. Given the significant workload, there may be differences in practice patterns worldwide regarding the incorporation of image guidance and multimodality imaging techniques. From this aspect, our study may add to the literature with routine utilization of these contemporary strategies in patient management.

In conclusion, incorporation of multimodality imaging in target definition of bone metastases with soft tissue component may be utilized for improving the accuracy for precise RT despite the need for further supporting evidence.

\section{References}

1. Brodowicz T, Hadji P, Niepel D, Diel I (2017) Early identification and intervention matters: A comprehensive review of current evidence and recommendations for the monitoring of bone health in patients with cancer. Cancer Treat Rev 61 : 23-34. Link: http://bit.ly/38WmKvg

2. Coleman RE (2006) Clinical features of metastatic bone disease and risk of skeletal morbidity. Clin Cancer Res 12: 6243s-6249s. Link: http://bit.ly/3cOGZMh

3. Jimenez-Andrade JM, Mantyh WG, Bloom AP, Ferng AS, Geffre CP, et al (2010) Bone cancer pain. Ann N Y Acad Sci 1198: 173-181.

4. Mantyh PW (2014) Bone cancer pain: from mechanism to therapy. Curr Opin Support Palliat Care 8: 83-90. Link: http://bit.ly/3eVxQo4

5. Maurizi A, Rucci N (2018) The Osteoclast in Bone Metastasis: Player and Target. Cancers (Basel) 10: 218. Link: http://bit.ly/3eRVD8p

6. Zajączkowska R, Kocot-Kępska M, Leppert W, Wordliczek J (2019) Bone Pain in Cancer Patients: Mechanisms and Current Treatment. Int J Mo Sci 20: 6047. Link: http://bit.ly/3s1ryqD

7. Selvaggi G, Scagliotti GV (2005) Management of bone metastases in cancer: a review. Crit Rev Oncol Hematol 56: 365-378. Link: http://bit.ly/3c0HT9|

8. De Felice F, Piccioli A, Musio D, Tombolini V (2017) The role of radiation therapy in bone metastases management. Oncotarget 8 : 25691-25699. Link: http://bit.ly/3ltpIMR

9. Lutz S, Berk L, Chang E, Chow E, Hahn C, et al. (2011) Palliative radiotherapy for bone metastases: an ASTRO evidence-based guideline. Int J Radiat Oncol Biol Phys 79: 965-976. Link: http://bit.ly/2NvOIX4

10. Moraes FY, Chen X, Yan M, Spratt DE, Redmond K, et al. (2020) Evolving Role of Stereotactic Body Radiation Therapy in the Management of Spine Metastases: Defining Dose and Dose Constraints. Neurosurg Clin N Am 31: 167-189. Link: http://bit.ly/38Tndho

11. Spencer KL, van der Velden JM, Wong E, Seravalli E, Sahgal A, et al (2019) Systematic Review of the Role of Stereotactic Radiotherapy for Bone Metastases. J Natl Cancer Inst 111: 1023-1032. Link: http://bit.ly/3s12qAo

12. De la Pinta C (2020) SBRT in non-spine bone metastases: a literature review. Med Oncol 37: 119. Link: http://bit.ly/3vQNIOK

13. Sager O, Demiral S, Dincoglan F, Beyzadeoglu M (2021) Assessment of posterior fossa target definition by multimodality imaging for patients with medulloblastoma. J Surg Surgical Res 7: 037-041.

14. Sager O, Dincoglan F, Demiral S, Beyzadeoglu M (2021) Evaluation of Changes in Tumor Volume Following Upfront Chemotherapy for Locally Advanced Non Small Cell Lung Cancer (NSCLC). Glob J Cancer Ther. 7: 031-034.

15. Dincoglan F, Demiral S, Sager O, Beyzadeoglu M (2021) Evaluation of Target Definition for Management of Myxoid Liposarcoma (MLS) with Neoadjuvant Radiation Therapy (RT). Biomed J Sci Tech Res 33: 26171-26174. 
16. Demiral S, Dincoglan F, Sager O, Beyzadeoglu M (2021) Assessment of Multimodality Imaging for Target Definition of Intracranial Chondrosarcomas. Canc Therapy Oncol Int J 18: 555981.

17. Dincoglan F, Sager O, Demiral S, Beyzadeoglu M (2021) Impact of Multimodality Imaging to Improve Radiation Therapy (RT) Target Volume Definition for Malignant Peripheral Nerve Sheath Tumor (MPNST). Biomed J Sci Tech Res 34: $26734-26738$

18. Sager O, Dincoglan F, Demiral S, Beyzadeoglu M (2021) Treatment Volume Determination for Irradiation of Recurrent Nasopharyngeal Carcinoma with Multimodality Imaging: An Original Article. ARC Journal of Cancer Science 6 : 18-23.

19. Demiral S, Dincoglan F, Sager O, Beyzadeoglu M (2021) Multimodality Imaging Based Target Definition of Cervical Lymph Nodes in Precise Limited Field Radiation Therapy (Lfrt) for Nodular Lymphocyte Predominant Hodgkin Lymphoma (NIphl). ARC Journal of Cancer Science 6: 06-11.

20. Dincoglan F, Sager O, Demiral S, Beyzadeoglu M (2021) Target Definition of orbital Embryonal Rhabdomyosarcoma (Rms) by Multimodality Imaging: An Original Article. ARC Journal of Cancer Science 6: 12-17.

21. Sager O, Dincoglan F, Demiral S, Beyzadeoglu M (2020) Assessment of Targe Volume Definition for Irradiation of Hemangiopericytomas: An Original Article. Canc Ther Oncol Int J 17. Link: https://bit.ly/3bMfQub

22. Demiral S, Beyzadeoglu M, Dincoglan F, Sager O (2020) Evaluation of Radiosurgery Target Volume Definition for Tectal Gliomas with Incorporation of Magnetic Resonance Imaging (MRI): An Original Article. Biomedical Journal of Scientific \& Technical Research (BJSTR) 27: 20543-20547. Link: https://bit.ly/3bNkOIO

23. Sager O, Dincoglan F, Demiral S, Beyzadeoglu M (2020) Evaluation of Treatment Volume Determination for Irradiation of chordoma: an Origina Article. International Journal of Research Studies in Medical and Health Sciences 5: 3-8. Link: https://bit.ly/3rSbLKE

24. Dincoglan F, Beyzadeoglu M, Demiral S, Sager O (2020) Assessment of Treatment Volume Definition for Irradiation of Spinal Ependymomas: an Original Article. ARC Journal of Cancer Science 6: 1-6. Link: https://bit.ly/2Q387zE

25. Dincoglan F, Demiral S, Sager O, Beyzadeoglu M (2020) Utility of Multimodality Imaging Based Target Volume Definition for Radiosurgery of Trigeminal Neuralgia: An Original Article. Biomed J Sci Tech Res 26: 19728-19732. Link: https://bit.ly/2OXKAja

26. Sager O, Dincoglan F, Demiral S, Beyzadeoglu M (2020) Evaluation of Target Volume Determination for Irradiatıon of Pilocytic Astrocytomas: An Original Article. ARC Journal of Cancer Science 6: 1-5. Link: https://bit.ly/3rRdSyc

27. Sager O, Demiral S, Dincoglan F, Beyzadeoglu M (2020) Target Volume Definition for Stereotactic Radiosurgery (SRS) Of Cerebral Cavernous Malformations (CCMs). Canc Therapy Oncol Int J 15: 555917. Link: https://bit.ly/3ldxev6

28. Beyzadeoglu M, Dincoglan F, Sager O, Demiral S (2020) Determination of Radiosurgery Treatment Volume for Intracranial Germ Cell Tumors (GCTS). Asian Journal of Pharmacy, Nursing and Medical Sciences 8: 18-23. Link: https://bit.ly/3toPNzn

29. Demiral S, Beyzadeoglu M, Dincoglan F, Sager O (2020) Assessment of Target Volume Definition for Radiosurgery of Atypical Meningiomas with Multimodality Imaging. Journal of Hematology and Oncology Research 3: 14 21. Link: https://bit.ly/3eFbEy7

30. Sager O, Dincoglan F, Demiral S, Beyzadeoglu M (2020) Radiosurgery Treatment Volume Determination for Brain Lymphomas with and without Incorporation of Multimodality Imaging. Journal of Medical Pharmaceutical and Allied Sciences 9: 2398-2404. Link: https://bit.ly/3eyrkn0.

31. Beyzadeoglu M, Dincoglan F, Demiral S, Sager O (2020) Target Volume Determination for Precise Radiation Therapy (RT) of Central Neurocytoma:
An Original Article. International Journal of Research Studies in Medical and Health Sciences 5: 29-34.

32. Dincoglan F, Sager O, Demiral S, Beyzadeoglu M (2019) Incorporation of Multimodality Imaging in Radiosurgery Planning for Craniopharyngiomas: An Original Article. SAJ Cancer Sci 6: 103. Link: https://bit.ly/2NiFkpL

33. Sager O, Dincoglan F, Demiral S, Gamsiz H, Uysal B, et al. (2019) Evaluation of the Impact of Magnetic Resonance Imaging (MRI) on Gross Tumor Volume (GTV) Definition for Radiation Treatment Planning (RTP) of Inoperable High Grade Gliomas (HGGs). Concepts in Magnetic Resonance Part A 2019 4282754. Link: https://bit.ly/3qK77Nn

34. Demiral S, Sager O, Dincoglan F, Beyzadeoglu M (2019) Assessment of Computed Tomography (CT) And Magnetic Resonance Imaging (MRI) Based Radiosurgery Treatment Planning for Pituitary Adenomas. Canc Therapy Oncol Int J 13: 555857. Link: https://bit.ly/3qKvfPR

35. Demiral S, Sager O, Dincoglan F, Beyzadeoglu M (2019) Assessment of target definition based on Multimodality imaging for radiosurgical Management of glomus jugulare tumors (GJTs). Canc Therapy Oncol Int J 15: 555909. Link: https://bit.ly/3vp4hB2

36. Sager O, Dincoglan F, Demiral S, Gamsiz H, Uysal B, et al. (2019) Utility of Magnetic Resonance Imaging (Imaging) in Target Volume Definition for Radiosurgery of Acoustic Neuromas. Int $\mathrm{J}$ Cancer Clin Res 6: 119. Link: https://bit.ly/3bMhr3

37. Sager O, Dincoglan F, Demiral S, Beyzadeoglu M (2019) Evaluation of Radiosurgery Target Volume Determination for Meningiomas Based on Computed Tomography (CT) And Magnetic Resonance Imaging (MRI). Cancer Sci Res Open Access 5: 1-4. Link: https://bit.ly/3vp4hkw

38. Dincoglan F, Sager O, Demiral S, Beyzadeoglu M (2019) Multimodality Imaging for Radiosurgical Management of Arteriovenous Malformations. Asian Journal of Pharmacy, Nursing and Medical Sciences 7: 7-12. Link: https://bit.ly/3cwnFmX

39. Beyzadeoglu M, Sager O, Dincoglan F, Demiral S (2019) Evaluation of Target Definition for Stereotactic Reirradiation of Recurrent Glioblastoma. Arch Can Res 7: 3. Link: https://bit.ly/20pxR90

40. Demiral S, Sager O, Dincoglan F, Uysal B, Gamsiz H, et al. (2018) Evaluation of Target Volume Determination for Single Session Stereotactic Radiosurgery (SRS) of Brain Metastases. Canc Therapy Oncol Int J 12: 555848. Link: https://bit.ly/2MXRS1K

41. Sager O, Dincoglan F, Demiral S, Uysal B, Gamsiz H, et al. (2021) Omission of Radiation Therapy (RT) for Metaplastic Breast Cancer (MBC): A Review Article. International Journal of Research Studies in Medical and Health Sciences 6 : 10-15

42. Sager O, Dincoglan F, Demiral S, Uysal B, Gamsiz H, et al. (2020) Adaptive radiation therapy of breast cancer by repeated imaging during irradiation. World J Radiol 12: 68-75. Link: https://bit.ly/3bKVSzT

43. Sager O, Dincoglan F, Demiral S, Uysal B, Gamsiz H, et al. (2019) Breathing adapted radiation therapy for leukemia relapse in the breast: A case report. World J Clin Oncol 10: 369-374. Link: https://bit.ly/3qNJsLS

44. Sager O, Dincoglan F, Demiral S, Uysal B, Gamsiz H, et al. (2019) Utility of Molecular Imaging with 2-Deoxy-2-[Fluorine-18] Fluoro-DGlucose Positron Emission Tomography (18F-FDG PET) for Small Cell Lung Cancer (SCLC) A Radiation Oncology Perspective. Curr Radiopharm 12: 4-10. Link: https://bit.ly/3bKW7eh

45. Sager O, Dincoglan F, Uysal B, Demiral S, Gamsiz H, et al. (2018) Evaluation of adaptive radiotherapy (ART) by use of replanning the tumor bed boost with repeated computed tomography $(\mathrm{CT})$ simulation after whole breast irradiation (WBI) for breast cancer patients having clinically evident seroma. Jpn J Radio 36: 401-406. Link: https://bit.ly/3bOpQmV

46. Sager O, Dincoglan F, Uysal B, Demiral S, Gamsiz H, et al. (2017) Splenic Irradiation: A Concise Review of the Literature. J App Hem BI Tran 1: 101 Link: https://bit.ly/3eBmtkP. 
47. Sager O, Beyzadeoglu M, Dincoglan F, Demiral S, Uysal B, et al. (2015) Adaptive splenic radiotherapy for symptomatic splenomegaly management in myeloproliferative disorders. Tumori 101: 84-90. Link: https://bit.ly/2OAe0DT

48. Özsavaş EE, Telatar Z, Dirican B, Sağer Ö, Beyzadeoğlu M (2014) Automatic segmentation of anatomical structures from CT scans of thorax for RTP. Comput Math Methods Med 2014: 472890. Link: https://bit.ly/3qOsjC3

49. Dincoglan F, Beyzadeoglu M, Sager O, Oysul K, Kahya YE, et al. (2013) Dosimetric evaluation of critical organs at risk in mastectomized left-sided breast cancer radiotherapy using breath-hold technique. Tumori 99: 76-82. Link: https://bit.ly/20oOmSM

50. Sager O, Beyzadeoglu M, Dincoglan F, Oysul K, Kahya YE, et al. (2012) Evaluation of active breathing control-moderate deep inspiration breath-hold in definitive non-small cell lung cancer radiotherapy. Neoplasma 59: 333-340. Link: http://bit.ly/3cVtnNh

51. Sager Ö, Dinçoglan F, Gamsiz H, Demiral S, Uysal B, et al. (2012) Evaluation of the impact of integrated [18f]-fluoro-2-deoxy-D-glucose positron emission tomography/computed tomography imaging on staging and radiotherapy treatment volume definition of nonsmall cell lung cancer. Gulhane Med $J 54$ : 220-227. Link: https://bit.ly/3htqTt5

52. Sager O, Beyzadeoglu M, Dincoglan F, Oysul K, Kahya YE, et al. (2012) The Role of Active Breathing Control-Moderate Deep Inspiration Breath-Hold (ABC$\mathrm{mDIBH}$ ) Usage in non-Mastectomized Left-sided Breast Cancer Radiotherapy: A Dosimetric Evaluation. UHOD - Uluslararasi Hematoloji-Onkoloji Dergisi 22 147-155. Link: http://bit.ly/3bMn7dF

53. Sager O, Beyzadeoglu M, Dincoglan F, Demiral S, Gamsiz H, et al. (2020) Multimodality management of cavernous sinus meningiomas with less extensive surgery followed by subsequent irradiation: Implications for an improved toxicity profile. J Surg Surgical Res 6: 056-061. Link: https://bit.ly/3toikvl

54. Dincoglan F, Beyzadeoglu M, Sager O, Demiral S, Uysal B, et al. (2020) A Concise Review of Irradiation for Temporal Bone Chemodectomas (TBC) Arch Otolaryngol Rhinol 6: 016-020. Link: https://bit.ly/3cymTWr

55. Beyzadeoglu M, Sager O, Dincoglan F, Demiral S, Uysal B, et al. (2020) Single Fraction Stereotactic Radiosurgery (SRS) versus Fractionated Stereotactic Radiotherapy (FSRT) for Vestibular Schwannoma (VS). J Surg Surgical Res 6 : 062-066. Link: https://bit.ly/3qVHOs1

56. Dincoglan F, Sager O, Demiral S, Gamsiz H, Uysal B, et al. (2019) Fractionated stereotactic radiosurgery for locally recurrent brain metastases after failed stereotactic radiosurgery. Indian J Cancer 56: 151-156. Link: https://bit.ly/3tkGss6

57. Dincoglan F, Sager O, Uysal B, Demiral S, Gamsiz H, et al. (2019) Evaluation of hypofractionated stereotactic radiotherapy (HFSRT) to the resection cavity after surgical resection of brain metastases: A single center experience Indian J Cancer 56: 202-206. Link: https://bit.ly/38EOeVM

58. Demiral S, Dincoglan F, Sager O, Uysal B, Gamsiz H, et al. (2018) Contemporary Management of Meningiomas with Radiosurgery. Int J Radiol Imaging Technol 80: 187-190. Link: https://bit.ly/3rJwiRw

59. Dincoglan F, Sager O, Demiral S, Uysal B, Gamsiz H, et al. (2017) Radiosurgery for recurrent glioblastoma: A review article. Neurol Disord Therap 1: 1-5. Link: https://bit.ly/30JZTOQ

60. Demiral S, Dincoglan F, Sager O, Gamsiz H, Uysal B, et al. (2016) Hypofractionated stereotactic radiotherapy (HFSRT) for who grade I anterior clinoid meningiomas (ACM). Jpn J Radiol 34: 730-737. Link: https://bit.ly/30FFBpK

61. Gamsiz H, Beyzadeoglu M, Sager O, Demiral S, Dincoglan F, et al. (2015)
Evaluation of stereotactic body radiation therapy in the management of adrenal metastases from non-small cell lung cancer. Tumori 101: 98-103. Link: https://bit.ly/3tkGpNa

62. Dincoglan F, Beyzadeoglu M, Sager O, Demiral S, Gamsiz H, et al. (2015) Management of patients with recurrent glioblastoma using hypofractionated stereotactic radiotherapy. Tumori 101: 179-184. Link: https://bit.ly/3eDf4BN

63. Sager O, Dincoglan F, Beyzadeoglu M (2015) Stereotactic radiosurgery of glomus jugulare tumors: Current concepts, recent advances and future perspectives. CNS Oncol 4: 105-114. Link: https://bit.ly/3/h1FjT

64. Gamsiz H, Beyzadeoglu M, Sager O, Dincoglan F, Demiral S, et al. (2014) Management of pulmonary oligometastases by stereotactic body radiotherapy. Tumori 100: 179-183. Link: https://bit.ly/2Q7uCDH

65. Demiral S, Beyzadeoglu M, Sager O, Dincoglan F, Gamsiz H, et al. (2014) Evaluation of linear accelerator (linac)-based stereotactic radiosurgery (srs) for the treatment of craniopharyngiomas. UHOD - Uluslararasi HematolojiOnkoloji Dergisi 24: 123-129. Link: https://bit.ly/3vr4Dql

66. Demiral S, Beyzadeoglu M, Sager O, Dincoglan F, Gamsiz H, et al. (2014) Evaluation of linear accelerator (linac)-based stereotactic radiosurgery (srs) for the treatment of craniopharyngiomas. UHOD - Uluslararasi HematolojiOnkoloji Dergisi 24: 123-129. Link: https://bit.ly/3vr4Dql

67. Dincoglan F, Sager O, Gamsiz H, Uysal B, Demiral S, et al. (2014) Managemen of patients with $\geq 4$ brain metastases using stereotactic radiosurgery boost after whole brain irradiation. Tumori 100: 302-306. Link: https://bit.ly/3rOh6CN

68. Sager O, Beyzadeoglu M, Dincoglan F, Uysal B, Gamsiz H, et al. (2014) Evaluation of linear accelerator (LINAC)-based stereotactic radiosurgery (SRS) for cerebral cavernous malformations: A 15-year single-center experience. Ann Saudi Med 34: 54-58. Link: https://bit.ly/3rPpuBM.

69. Sager O, Beyzadeoglu M, Dincoglan F, Gamsiz H, Demiral S, et al. (2014) Evaluation of linear accelerator-based stereotactic radiosurgery in the management of glomus jugulare tumors. Tumori 100: 184-188. Link: https://bit.ly/38F16eL

70. Sager O, Beyzadeoglu M, Dincoglan F, Demiral S, Uysal B, et al. (2013) Management of vestibular schwannomas with linear accelerator-based stereotactic radiosurgery: a single center experience. Tumori 99: 617-622. Link: https://bit.ly/3bMgoAf

71. Demiral S, Beyzadeoglu M, Uysal B, Oysul K, Kahya YE, et al. (2013) Evaluation of stereotactic body radiotherapy (SBRT) boost in the management of endometrial cancer. Neoplasma 60: 322-327. Link: https://bit.ly/20Re4iD

72. Dincoglan F, Beyzadeoglu M, Sager O, Uysal B, Demiral S, et al. (2013) Evaluation of linear accelerator-based stereotactic radiosurgery in the management of meningiomas: A single center experience. J Buon 18: 717 722. Link: https://bit.ly/3litoRa

73. Dincoglan F, Sager O, Gamsiz H, Uysal B, Demiral S, et al. (2012) Stereotactic radiosurgery for intracranial tumors: A single center experience. Gulhane Med J 54: 190-198. Link: https://bit.ly/3cYmv1J

74. Dincoglan F, Beyzadeoglu M, Sager O, Oysul K, Sirin S et al. (2012) Image guided positioning in intracranial non-invasive stereotactic radiosurgery for the treatment of brain metastasis. Tumori 98: 630-635. Link: http://bit.ly/2BOtOZA

75. Sirin S, Oysul K, Surenkok S, Sager O, Dincoglan F, et al. (2011) Linear accelerator-based stereotactic radiosurgery in recurrent glioblastoma: A single center experience. Vojnosanit Pregl 68: 961-966. Link: http://bit.ly/3hqfBGb

Copyright: () 2021 Sager 0, et al. This is an open-access article distributed under the terms of the Creative Commons Attribution License, which permits unrestricted use, distribution, and reproduction in any medium, provided the original author and source are credited. 